\title{
Indo-Swiss Symposium on Cohorts and Biobanks with special reference to chronic non-communicable diseases
}

\author{
KR Thankappan ${ }^{1 *}$, Mitchell G Weiss ${ }^{2}$, Probst-Hensch Nicole ${ }^{3}$, K Radhakrishnan $^{4}$ \\ From IndoSwiss Symposium on Cohorts and Biobanks (ISSCB) \\ Trivandrum, India. 27-28 January 2012
}

\begin{abstract}
An indo-Swiss symposium on cohorts and biobanks with special reference to chronic non-communicable diseases was organized at Sree Chitra Tirunal Institute for Medical Sciences and Technology, Trivandrum, India on 27-28 January 2012. The symposium was sponsored by the Department of Science and Technology (DST), Government of India in the frame work of the IndoSwiss Joint Research Programme (ISJRP) and organized in association with the Swiss Tropical and Public Health Institute, Basel, Switzerland. The objectives of the symposium were: (1) consider the value and priority of cohorts and bio-banks to explain vulnerability and risk factors, and to guide policy, (2) review Indian and Swiss experience and approaches to establishing and managing various cohorts, (3) clarify cross-cutting implications and prospects for cohort planning in India and Switzerland, and for particular chronic diseases and (4) examine ethical issues to be addressed in design and planning of cohort studies and bio-banking.
\end{abstract}

\begin{abstract}
Authors' details
'Achutha Menon Centre for Health Science Studies, Sree Chitra Tirunal Institute for Medical Sciences and Technology, Trivandrum, India. 2University of Basel, and former Head, Department of Epidemiology and Public Health, Swiss TPH, Basel, Switzerland. ${ }^{3}$ University of Basel, and Department of Epidemiology \& Public Health, Swiss Tropical and Public Health Institute, Basel, Switzerland. ${ }^{4}$ Sree Chitra Tirunal Institute for Medical Sciences and Technology, Trivandrum, India.
\end{abstract}

Published: 30 August 2013

\footnotetext{
* Correspondence: kavumpurathu@yahoo.com

${ }^{1}$ Achutha Menon Centre for Health Science Studies, Sree Chitra Tirunal

Institute for Medical Sciences and Technology, Trivandrum, India

Full list of author information is available at the end of the article
}

doi:10.1186/1753-6561-7-S5-A1

Cite this article as: Thankappan et al:: Indo-Swiss Symposium on Cohorts and Biobanks with special reference to chronic non-communicable diseases. BMC Proceedings 2013 7(Suppl 5):A1.
Submit your next manuscript to BioMed Central and take full advantage of:

- Convenient online submission

- Thorough peer review

- No space constraints or color figure charges

- Immediate publication on acceptance

- Inclusion in PubMed, CAS, Scopus and Google Scholar

- Research which is freely available for redistribution

Submit your manuscript at www.biomedcentral.com/submit

\section{() Biomed Central}

C Biomed Central 